\title{
Expression of Bacillus thuringiensis insecticidal protein gene in transgenic oil palm
}

\author{
Mei-Phing Lee ${ }^{\dagger}$ \\ Oil Palm Biotechnology Group \\ School of Bioscience and Biotechnology \\ Faculty of Science and Technology \\ Universiti Kebangsaan Malaysia \\ 43600 Bangi \\ Selangor, Malaysia \\ E-mail: phing_san@yahoo.com \\ Li-Huey Yeun \\ Oil Palm Biotechnology Group \\ School of Bioscience and Biotechnology \\ Faculty of Science and Technology \\ Universiti Kebangsaan Malaysia \\ 43600 Bangi \\ Selangor, Malaysia \\ E-mail: lihuey@hotmail.com \\ Ruslan Abdullah* \\ Oil Palm Biotechnology Group \\ School of Bioscience and Biotechnology \\ Faculty of Science and Technology \\ Universiti Kebangsaan Malaysia \\ 43600 Bangi \\ Selangor, Malaysia \\ Tel: 603-89215698 \\ Fax: 603-89252698 \\ E-mail: russzn@ukm.my
}

Financial support: Ministry of Science, Technology and Innovation, Malaysia (IRPA 01-02-02-0168 and IRPA 09-02-02-0033.

Keywords: $\operatorname{CryIA(b)}$ gene, gene expression, insect resistance, oil palm transformation, rapid detection system, transgenic oil palm.

$\dagger$ : Passed away December 2005.

Abbreviations: $\quad$ DGT: direct gene transfer

IEs: immature embryos

Oil palm, like all other crops, is susceptible to attack from several insect pests causing significant reduction in productivity. In the past, cry genes from Bacillus thuringiensis have been reported to be effective in conferring resistance towards insect pests in crops such as corn and rice. One of the advantages of these toxin proteins is their specificity towards certain harmful insects. A rapid and efficient method was developed for the transformation and evaluation of $\operatorname{CryIA(b)}$ expression in oil palm. A recombinant vector was introduced into immature embryos (IEs) of oil palm via the biolistic method. More than 700 putative transformed IEs from independent transformation events were generated. Transient transformation efficiency of 81-100\% was achieved. We found that pretreatment of target tissues with phytohormones is essential for increasing the transformation efficiency. This finding could enable higher transformation rate in oil palm that was previously difficult to transform. PCR analysis further confirmed the presence of the $\operatorname{CryIA(b)}$ in the transformed tissues. Expression of $\mathrm{CryI} A(b)$ from PCR-positive samples was further confirmed using a rapid gene expression detection system. This novel and rapid detection system could serve as a good opportunity to analyze the impact of transgenes upon transfer to the new environment, especially for crops with long generation cycle, such as oil palm.

Oil palm (Elaeis guineensis Jacq.) is the source of the most sought-after edible oil in the world market. With the advent of new biotechnology tools, in particular gene manipulation, palm oil monopoly as a commodity is challenged by other oil-bearing crops such as soybean (Kinney et al. 2001), sunflower seed (Osorio et al. 1995) and rape seed (Ramachandran et al. 2000; Dehesh et al. 2001) that have been successfully modified genetically.

*Corresponding author 
Thus, it is imperative to increase oil palm yield to meet the ever-increasing global demands and also to expand its uses. In the past, conventional breeding of oil palm is a lowefficiency and time-consuming process due to its long reproduction cycle and slow seed maturation (Mayes et al. 2000). Current conventional breeding programmes for oil palm are supported by modern biotechnology approaches such as the use of tissue culture, genetic transformation and marker-aided selection, to further improve oil palm commercial value and productivity (Mayes et al. 2000). Over the past 10 years, our group has been actively involved in genetic engineering of oil palm (Abdullah et al. 2003; Abdullah et al. 2005). Although many studies have been done, but there are very few publications on genetic manipulation of oil palm, probably due to the high commercial implication tagged to the crop and also due to the crops own physiological characteristics such as long generation cycle. Special emphasis was placed initially in
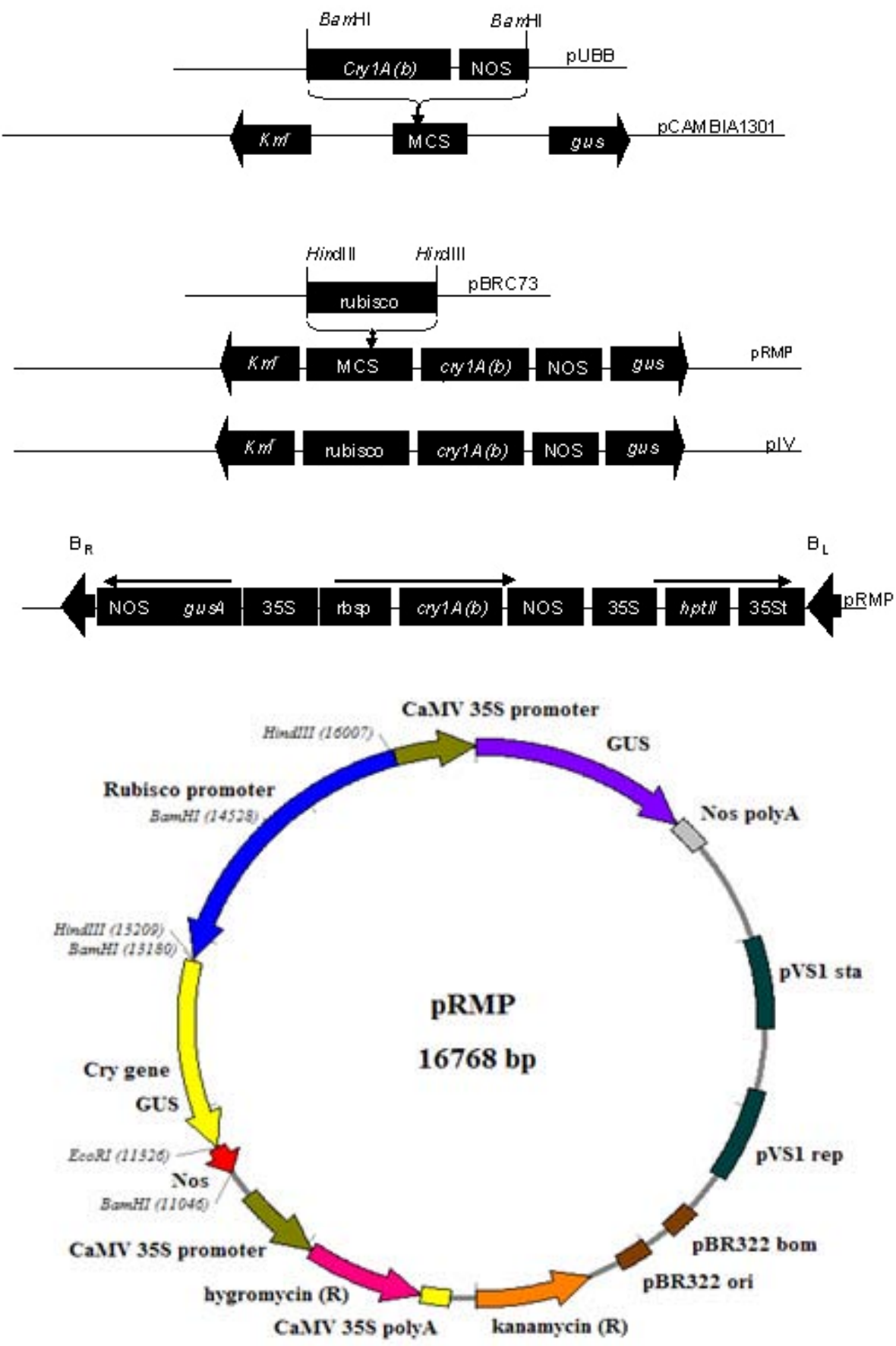

Figure 1. Construction of recombinant plasmid pRMP. pRMP contains hptll and gusA both regulated by CaMV $35 \mathrm{~S}$ promoter, cry1Ab gene under the transcriptional control of a rubisco promoter with a nopaline synthase terminator, and located within the T-DNA right and left border sequences. Arrows indicate the direction of transcription. 35S, CaMV 35S promoter; NOS, nos polyA terminator; rbsp, rubisco promoter; 35St, CaMV 35S polyA; BR, right border; BL, left border; $\mathrm{Km}^{\mathrm{r}}$, kanamycin resistance. 
developing techniques for genes transfer into oil palm, both using direct gene transfer (DGT) and Agrobacteriummediated approaches. Both techniques were then used to transfer useful genes such as cowpea trypsin inhibitor (CpTI) (Abdullah et al. 2003) and Bacillus thuringiensis $(B t)$ crystal insecticidal protein genes, to address problems related to insect pests (Sharma et al. 2000; Sharma et al. 2002) and chitinase (to address problems related to basal stem rot).

Transgenic plants such as tomato, tobacco, cabbage and rice containing CryIA(b) gene have been obtained using both DGT and Agrobacterium transformation methods (Cheng et al. 1998; Jouanin et al. 1998; Robinson, 1999; Bhattacharya et al. 2002). In this article, we report successful transformation of oil palm using particle bombardment for expression of an agronomic trait. We have carried out the construction of the CryIA(b) gene cassette (Sardana et al. 1996) which have been modified to express highly in plants, particularly oil palm. In the investigation, the synthetic CryIA(b) was introduced into oil palm, data for successful transformation and expression of the gene within the oil palm tissue were also presented. The CryIA(b) gene when expressed produced proteins which upon crystallization are highly toxic to Lepidoptera (Masson et al. 1999; Reardon et al. 2004), among which Metisa plana is a major insect pest for oil palm (Wood, 1968). Using our established DGT methods for oil palm, we then developed a rapid detection system for evaluating transgene expression among putative transformed tissues. The procedure developed is very sensitive, rapid and eliminates the long waiting period for transgenic plants to reach maturity.

\section{MATERIALS AND METHODS}

\section{Transformation vector}

Escherichia coli strain DH5 $\alpha$ was used as plasmid host for the construction of transformation vectors. Standard cloning techniques (Sambrook et al. 2001) were used to construct the recombinant plasmid, pRMP as shown in Figure 1. The coding sequence for CryIA(b) gene, a derivative of plasmid pUBB (Prof. Illimaar Altosaar, University of Ottawa, Canada), and known to produce lepidopteran-specific $\delta$-endotoxin, was inserted into pCAMBIA 1301 cloning vector (Dr. Richard A. Jefferson, CAMBIA, Australia) using the BamHI site. The HindIII site was then deleted through the excision of the 3' end of the cassette. Subsequently, rubisco promoter, a derivative of pBRC73 (Dr. J. K. Kim, Myongyi University, Korea) was fused to the CryIA(b) coding sequence using the remaining HindIII site. The terminator sequence was then inserted into the vector using the EcoRI site, giving rise to a recombinant plasmid $\mathrm{pRMP}$. The integrity and integration of CryIA(b) was confirmed using restriction mapping, Southern blotting and sequencing. Apart from those present in the original parent plasmid pCAMBIA1301, the recombinant plasmid pRMP now also contains a chimearic
CryIA(b) gene under the transcriptional control of a rubisco promoter and terminated by a polyadenylation signal from the nopaline synthase gene (nos T). pRMP was then used in all subsequent transformation experiments.

\section{Plant material}

Oil palm (E. guineensis Jacq. var. tenera) samples were obtained from Pamol Plantations Sdn. Bhd. IEs were isolated from oil palm fruit bunch harvested 9-11 weeks after anthesis (WAA) according to protocols described earlier (Abdullah et al. 2005). Extracted IEs were cultured on $\mathrm{N}_{6}$ media with or without $2.5 \mathrm{mg} / 12,4 \mathrm{D}$ and incubated either in the dark at $28 \pm 1{ }^{\circ} \mathrm{C}$ for 4 weeks prior to bombardment.

\section{Transformation and GUS assay}

Pre-cultured IEs were bombarded using the PDS-1000/He particle delivery system (BioRad) following the procedure established elsewhere (Wright et al. 2001) with some modifications (Abdullah et al. 2005). All components of the chamber were surface-sterilized using $70 \%(\mathrm{v} / \mathrm{v})$ ethanol prior to bombardment. Plasmid DNA $(2.5 \mu \mathrm{g})$ were coated onto $3 \mathrm{mg}$ of resuspended gold particles. This was followed by the addition of $2.5 \mathrm{M} \mathrm{CaCl}_{2}$ and $0.1 \mathrm{M}$ spermidine. The mixture was vortexed and centrifuged for $1 \mathrm{~min}$. The DNAcoated particles were then washed with $100 \%(\mathrm{v} / \mathrm{v})$ ethanol. Target samples were placed $6 \mathrm{~cm}$ from the stopping screen and bombardment was performed at 900 psi. Nonbombarded IEs and those bombarded without DNA were used as control. Treatments were replicated three times. After bombardment, IEs were cultured on regeneration media. The embryos were sub-cultured every 4 weeks. The cultures were maintained at $24^{\circ} \mathrm{C}$ in a culture room under a $16 \mathrm{hrs}$ photoperiod. The expression of the gus A gene was assayed histochemically ( $\mathrm{Su}$ et al. 1998; Stangeland and Salehian, 2002) using X-Gluc (5-bromo-4-chloro-3-indole$\beta$-glucuronide) as substrate. GUS activity was inactivated with the addition of FAA solution [42.5\% (v/v) ethanol; $5 \%$ (v/v) glacial acetic acid; $10 \%$ (v/v) formalin].

\section{Isolation of genomic DNA and total RNA}

Genomic DNA and total RNA was isolated according to modified protocols of Doyle and Doyle (1990) and Verwoerd et al. (1989), respectively, using bombarded IEs 3 days after bombardment. Both DNA and RNA were quantified using a spectrophotometer.

\section{Expression analysis of CrylA(b) gene in IEs}

Oligonucleotides were designed to amplify region specific to the CryIA(b) coding sequence. For the purpose of evaluating transformation events, evidence of transgene presence is considered positive PCR or a positive expression assay for the gene of interest. All PCR and RTPCR were carried out according to the manufacturer's instruction manual (Promega). The primers set used were as follows: CRYF1 5'GGTTCGTTCTCGGACTAGTT and 


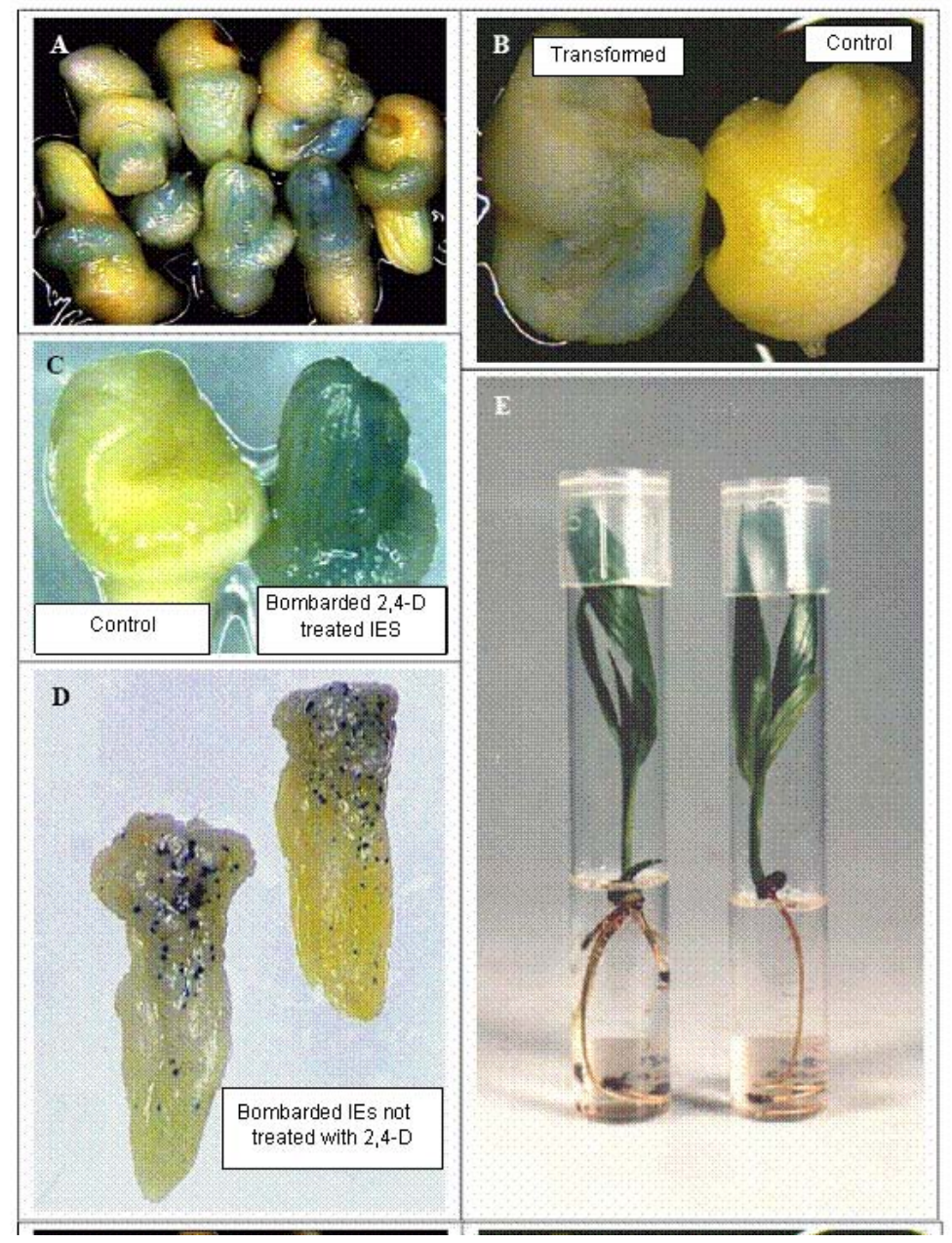

Figure 2. gusA expression patterns observed between transformed IEs treated with 2,4-D and those not treated with 2,4-D prior to bombardment.

(A) Randomly selected IEs assayed for gusA activity.

(B) In the presence of the gusA gene, substrate produced blue deposits as indicated by blue stains observed in successfully transformed cells and tissues. On the other hand, the absence of blue stain indicates the absence of gusA gene, which failed to produce blue deposit.

(C) Shades of blue stains (indicating gusA expression) were detected on transformed IEs spreading over the entire IEs treated with 2,4-D prior to bombardment. Prominent longitudinal blue stains probably along vascular bundles were also detected in 2,4-D treated IEs. No blue spot or stains were detected on all non-transformed sample (control).

(D) Only localized blue spots (distinct and isolated) were observed on IEs not treated with 2,4-D prior to bombardment. (E)Plantlets regenerated showed no difference in growth between those from double bombarded IEs (left) and from single bombardment (right).

CRYR1 5' CTGGTAAGTTGGGACACTGT. A total of 0.1-0.4 $\mu \mathrm{g}$ genomic DNA was used as template in a $50 \mu \mathrm{l}$ PCR reaction mix containing 25 pmol of each primer, $2.5 \mathrm{U}$ Taq DNA polymerase, $1.5 \mathrm{mM} \mathrm{MgCl} 2,1 \mathrm{X}$ buffer and 200 $\mu \mathrm{M}$ dNTP $(200 \mu \mathrm{M}$ each of dATP, dCTP, dGTP, dTTP) (Promega). The amplification conditions consisted of an initial DNA denaturation at $94^{\circ} \mathrm{C}$ for 5 min, followed by 1 min at $94^{\circ} \mathrm{C}, 1 \mathrm{~min}$ at $58^{\circ} \mathrm{C}$, and $1 \mathrm{~min}$ at $72^{\circ} \mathrm{C}$ for 30 cycles with a final extension cycle of $72^{\circ} \mathrm{C}$ for $7 \mathrm{~min}$. PCR products were electrophoresed on $1 \%(\mathrm{w} / \mathrm{v})$ agarose gel and analyzed under UV light after ethidium bromide staining. The presence of $C r y I A(b)$ gene was confirmed by Southern Blot analysis using the CryIA(b) gene as probe. Total RNA was isolated from tested PCR-positive samples. The same primer set (mentioned above) was used in RT-PCR. A total of $10 \mu \mathrm{g}$ total RNA was used as template in a $50 \mu \mathrm{l}$ PCR reaction mix containing 50 pmol each of reverse and forward primers, $1 \mathrm{X} \mathrm{AMV/Tfl} \mathrm{buffer,} 0.2 \mathrm{mM}$ dNTP, 1 $\mathrm{mM} \mathrm{MgSO} 4,0.1 \mathrm{U}$ reverse transcriptase and $0.1 \mathrm{U}$ Tfl DNA polymerase. Total RNA was reverse transcribed at $42^{\circ} \mathrm{C}$, for $1 \mathrm{hr}$ followed by PCR amplification as mentioned above. RT-PCR products were then separated on a $1.2 \%$ $(\mathrm{w} / \mathrm{v})$ agarose gel and blotted onto a nylon membrane. Hybridizations using DIG-labeled probes were then carried out according to Roche's instruction manual.

\section{RESULTS AND DISCUSSION}

\section{Characterization of transformation vector}

The open reading frame (ORF) of CryIA(b) was successfully cloned into pCAMBIA 1301 under the control 


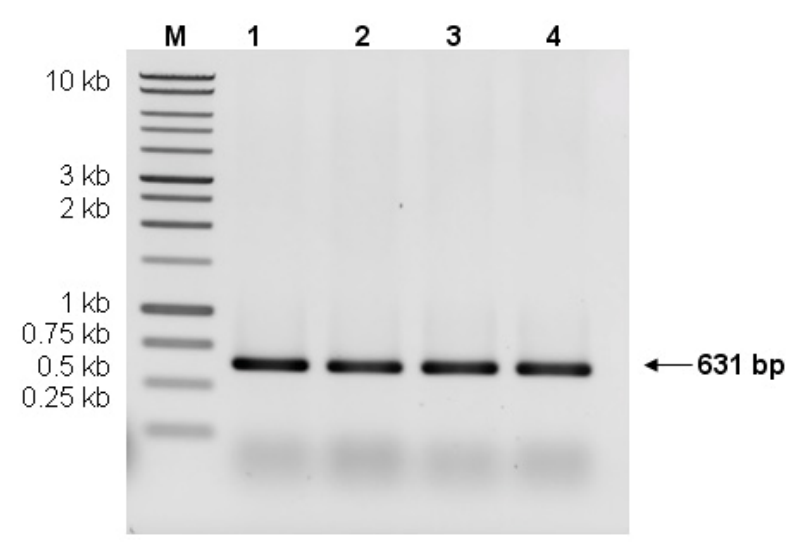

Figure 3. PCR analyses of putative transformed IEs for the presence of $\operatorname{CrylA}(b)$ gene. Genomic DNA was isolated from 3-day old putative transformed IEs and amplified using the CRYF1 and CRYR1 primer combination. All 15 samples tested showed the presence of the expected $631 \mathrm{bp}$, thus confirming the presence of $\operatorname{Cryl} A(b)$ gene in putative transformed IEs. Lane 1-4: examples of positive signals detected from all 15 samples tested. M, $1 \mathrm{~kb}$ DNA ladder marker.

of rubisco promoter in the sense orientation creating a new recombinant plasmid, pRMP (Figure 1). The orientation and integration of CryIA(b) in pRMP were confirmed through restriction mapping, Southern blotting and nucleotide sequencing. Southern blot analysis following multiple enzymatic digestions showed that $\operatorname{CryIA(b)}$ was successfully integrated into pRMP. Integration of CryIA(b) inpRMP was in-frame as confirmed through nucleotide sequencing with only the BamHI site connecting the rubisco promoter with the CryIA(b) coding sequence. Besides the CryIA(b) gene which is under the control of a rubisco promoter, the newly constructed pRMP also contains hptII (selectable marker gene) and gus (reporter gene), from the original pCAMBIA1301. Since all three genes cassette are flanked by the T-DNA right and left border sequences, thus, pRMP is useful for both biolisticmediated and Agrobacterium-mediated transformation experiments where they should be transferred in the process of successful gene transfer mediated by Agrobacterium.

\section{Pre-treatment of target tissues}

In our earlier work, we have shown that 2,4-D pretreatment of target tissues prior to particle bombardment and Agrobacterium infection (Abdullah et al. 2005) was essential for increasing the number of transformation events in target cells or tissues. IEs pre-cultured on $\mathrm{N}_{6}$ media supplemented with $2.5 \mathrm{mg} / 1$ 2,4-D prior to bombardment also showed different GUS expression pattern as compared to IEs maintained on hormone-free $\mathrm{N}_{6}$ media (Figure 2). In contrast, no blue spot or shade was observed on all control or non-bombarded tissues. The GUS-positive blue spots on IEs cultured on hormone-free $\mathrm{N}_{6}$ media were distinct, isolated and localized, whereas the GUS stains on 2,4-D pre-treated IEs spread over a larger area. There are two possibilities that may result in the expression of GUS that produced the blue stains over a larger area. First, the spread could be a consequence of a possible leakage between cells following damage caused during the process of bombardment. However, if this were the case, similar GUS expression pattern would also be observed on IEs pretreated on hormone-free $\mathrm{N}_{6}$ media since both samples were treated the same. Second, the spread of blue stains may be from relatively more cells that may have received the gus $A$ gene either through gene transfer (bombardment) or daughter cells derived from transformed cells undergoing cell divisions. This larger population of cells now possessing the gusA gene may have resulted in larger area of the tissues being stained blue following the expression of the transferred gene on the substrate. Therefore, it is more likely that the 2,4-D present in pre-treatment media must had influenced the expression pattern of the gusA gene transferred as observed in Figure 2. Being an auxin (Jain and Minocha, 2000; Pasternak et al. 2002), 2,4-D induces rapid cell division. Since the target tissues were pre-treated with 2,4-D prior to bombardment, therefore, upon successful transfer and integration, the gusA gene could easily be amplified together during subsequent cell divisions, thus giving rise to a wider spread of the blue stains observed (Abdullah et al. 2005). On the other hand, without 2,4-D, IEs pretreated on hormone-free $\mathrm{N}_{6}$ media did not undergo rapid cell division, but following the path of differentiation instead. Thus, the gusA stains detected in untreated IEs were isolated and distinct. In addition the stains were mainly localized in cells that may have received the transgene from bombardment only. Similar observations were also reported in rice transformation using Agrobacterium, where only target tissues cultured on 2,4D-containing media were capable of expressing GUS whereas those untreated tissues did not (unpublished data).

Yang et al. (1999) also claimed that cell divisions correlate with maximum transformation events, suggesting cell division is essential for cell competency. Competent cells have been associated to its susceptibility to receive foreign DNA during the process of transformation (Tang and Tian, 2003). Though we observed similar results in the case of oil palm, the reasons still remain unclear. However, it is believed that during cell division, active replication of DNA strand takes place. This is when chromosomes unwind and the double helix denatures (Gerald, 2002), hence exposing the fragile DNA. It is assumed that it was at this time that cells are most vulnerable to the invasion of foreign DNA. Illegitimate recombination between the vulnerable DNA and transgenes may have resulted in stable integration (Tzfira and Citovsky, 2002; Hohe and Reski, 2003). Therefore, factors that induce rapid cell division could play major role in ensuring higher transformation events.

\section{Transformation of oil palm}

Under our new experimental design, putatively transformed IEs were assayed 3 days after transformation. 750 IEs 

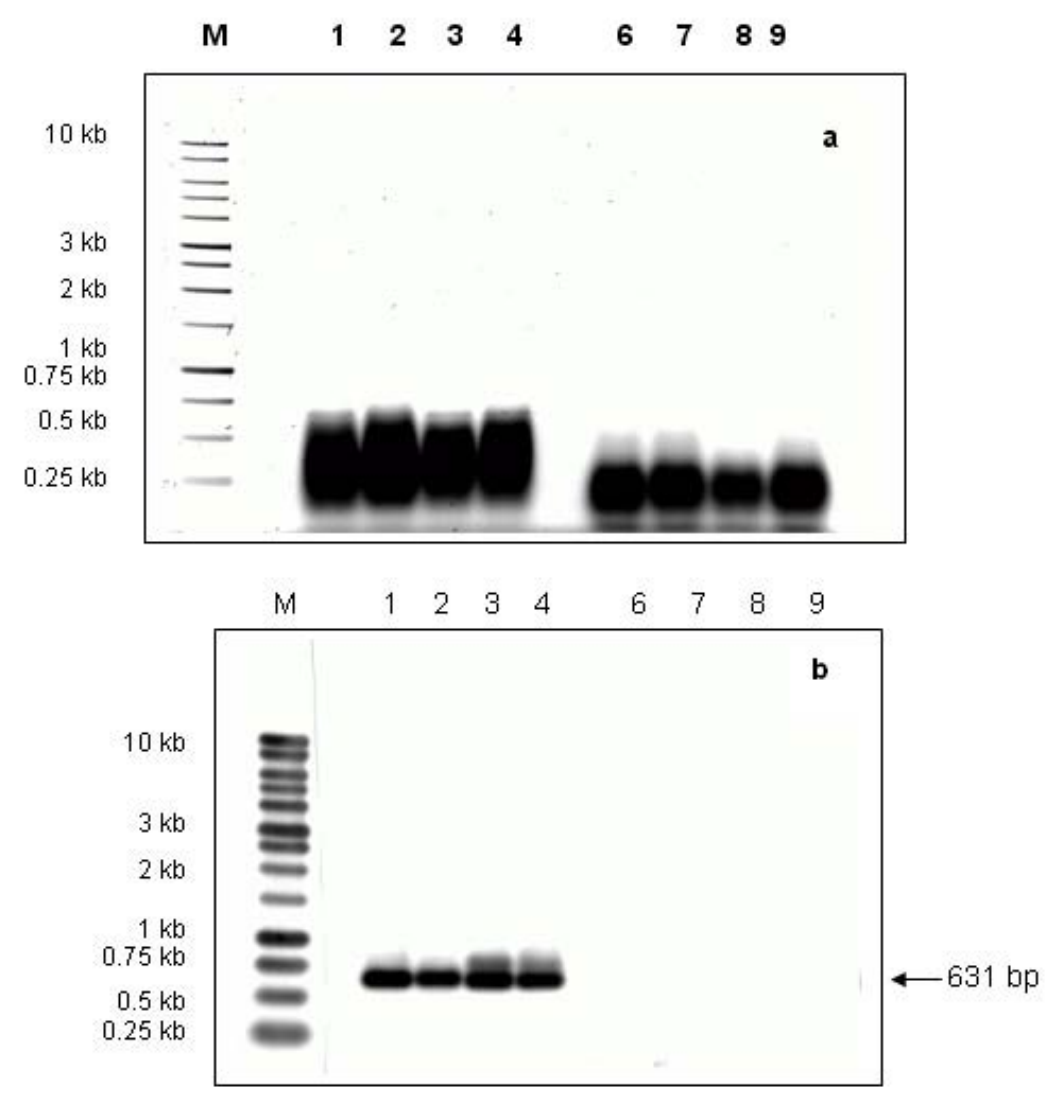

Figure 4. RT-PCR-Southern blot analysis of CryIA(b)transcripts in putative transformed IEs of oil palm.

(a) Lane 1-4: Electrophoresis of RT-PCR products on agarose gel. Probable bands corresponding to CrylA(b)transcripts were clouded with RNA and primers. Lane 6-9: Total RNA from putative transformed IEs subjected to PCR amplification without reverse transcription also produced no band, thus, further ascertained the absence of genomic DNA contamination that could produce a false positive signal. (b) Lane 1-4: Hybridization of RT-PCR products with CrylA(b)probe showing signals corresponding to the expected $631 \mathrm{bp}$ bands. Lane 6-9: Again, no signal was detected from all controls, thus confirming successful expression of CrylA(b) transgene in putative transformed IEs.

bombarded with pRMP were randomly selected and analyzed through histochemical staining (Figure 2). Transient GUS assay was used to evaluate the efficiency of gene transfer, where transformation efficiency is defined as the number of independent event recovered per explant bombarded (Wright et al. 2001). This was determined using result from the GUS assay. GUS-positive blue spots or stains were detected on randomly selected IEs assayed, suggesting gene transfer had taken place. In contrast, no blue spot was observed in all control samples assayed. Here, observation of one or more blue spots on a single IE is considered as one unit of expression (Klein et al. 1988). On average, the transient transformation efficiency of IEs bombarded once was recorded at $81 \%$ as compared to $100 \%$ for those subjected to double bombardment. Double or multiple bombardments is not normally practiced in other crops, as it would cause excessive wounding to target tissues (Jiang et al. 2000) resulting in eventual death. However, we believed that oil palm being a hardy plant could withstand certain amount of wounding to its tissues. Post bombardment observation showed that there was no excessive accumulation of phenolic compound in the culture medium, which would be the case for severely injured or dying oil palm tissues.

IEs from both treatments were cultured on hormone-free $\mathrm{N}_{6}$ media and regenerated to complete plantlets (Figure 2). Apart from about 3\% losses due to contamination, all bombarded IEs were regenerated into complete plantlets. The main objective of direct plant regeneration was to evaluate the impact of double bombardment on the plant as compared to single bombardment. Although the construct contained the hptII gene, antibiotic selection was not performed, as this would cause cell death to untransformed cells, thus inflicting additional stress to the limited transformed cells present. During antibiotic selection, dying cells inhibit nutrient supply to transgenic cells or excrete toxic compounds, which further impedes proliferation of transgenic cells to differentiate into transgenic plants (Ebinuma et al. 2001). This adverse effect would then influence IEs growth thus causing difficulties in data collection. Preliminary observation showed that there were no morphological differences between plantlets derived from IEs bombarded once or twice (Figure 2e). Similar 
observations were also noted in the formation of shoots and roots of plants from both groups. Plants from both groups also exhibited similar growth rate. Therefore, based on these observations, oil palm IEs can withstand double bombardment and would still be able to regenerate into healthy plantlets. However, these qualitative observations need further detailed study, especially on the plants performance upon maturity.

\section{Detection of transgene using PCR}

Many techniques have been developed to detect transgenes in $\mathrm{T}_{0}$ plants. These include PCR-based techniques followed by gel electrophoresis and detection, and are routinely used to detect transgenes in plants (Higuchi et al. 1992; Abedinia et al. 1997). Other techniques such as the use of molecular beacon assays (Kota et al. 1999) and FISH (Jin et al. 2002) had also been used. But this was not the case for slow growing plants like oil palm where detection of transgenes has always been a major problem. In this study, preliminary analyses on transformants were carried out by PCR analyses. Two primers, CRYF1 (nt 170-189) and CRYRI (nt 800-781) designed based on the coding sequence of CryIA(b) from plasmid pUBB with an expected PCR product of $631 \mathrm{bp}$ were used in subsequent PCR analyses. Genomic DNA isolated from fresh tissues of putative transformed and non-transformed (negative control) plants were used as templates in the analyses. In all cases, the expected $631 \mathrm{bp}$ bands were present in all 15 samples tested (Figure 3), indicating the presence of $\operatorname{CryIA(b)}$ in the genomic DNA of putative transformed plants. In contrast, no band was observed for all control samples. The experiments were repeated three times, giving the same result, suggesting successful gene transfer into oil palm via particle bombardment. The $100 \%$ transient transformation efficiency observed following PCR of CryIA(b) was similar to those observed earlier from GUS assay carried out using the same sample. Therefore, this further confirmed successful transfer of transgenes from pRMP into the oil palm tissues. However, the presence of CryIA(b) in putative transformed plants is no indication of its functionality in its new environment.

\section{Expression of CrylA(b) gene in oil palm}

Evaluation of transgene expression in $\mathrm{T}_{0}$ transgenic plants has always been difficult, especially when the transgenes undergoes various modifications in its new environment (Stam et al. 1998; Francis and Spiker, 2005). Many reports have shown that transgenes may be present in its new environment but were not expressed or expressed at a very low level making it undetectable. Failure for transgene to express may be due to mutations in the transgenes (Tinland, 1996), post-transcriptional gene silencing (Mitsuhara et al. 2002; Szittya et al. 2003), or chromatin-related transgene silencing (Francis and Spiker, 2005). In this study, although PCR analyses could easily detect the presence of CryIA(b) in the putative transformed plants, but attempts to detect its expression and functionality could not be easily carried out.
Several attempts using Northern blots to detect specific RNA sequences corresponding to the CryIA(b) gene was unsuccessful (data not shown). Subsequently, however, RTPCR analyses produced signals but could not be discriminated between those of the transgene [CryIA(b)] or contaminating primers and RNA (Figure 4a). However, when the RT-PCR products were blotted onto nylon membrane and hybridized against the $\operatorname{CryIA}(b)$ probe, it gave rise to positive signals with the expected size (631 bp, Figure 4b). The RT-PCR products were subsequently sequenced and showed that they were $100 \%$ homologous to the CryIA(b) from the original plasmid pUBB (Prof. Illimaar Altosaar, University of Ottawa, Canada). Thus, the presence of CryIA(b) mRNA transcripts shows that it is fully functional in oil palm, at least at the transcriptional level. Therefore, it can be concluded that the DNA and RNA specific to $\operatorname{Cry} I A(b)$ were actually present in putative transformed oil palm (as also shown in PCR analyses) but were below detectable level. However, once amplified (using RT-PCR), these could easily be detected as RT-PCR allows for reverse transcription of mRNA and amplification of the transcripts (Pfaffl and Hageleit, 2001). Combining Southern blot with RT-PCR further substantiate evidence on the functionality of CryIA(b) in oil palm. These observations are the first evidence on the functionality of a transgene in oil palm following transformation and could also serve as a sensitive detection assay as shown by the positive signals produced.

Most published papers on oil palm transformation (Chowdhury, 1997) used gusA, bar or ppt as reporter genes, which are easy to assay. In addition, there has been no conclusive report on transgenes expression in oil palm to date. In this regard, the fact that the CryIA(b) transcripts were detected directly using the RT-PCR-Southern Blotting method, it shows that not only the gene has been successfully transferred but is also successfully transcribed in its new environment. The combination of RT-PCRSouthern Blotting method is therefore useful to detect and study the fate of transgenes upon transfer in its new environment. This is essentially more important when multi-cellular tissues were used as target tissues, where only a minute fraction of cells within the tissues would be transiently transformed per bombarded explant. In such cases, it is quite impossible to determine the fate of the newly transferred transgene in its new environment. Similarly, it is often difficult to quantify transgene copy number in its new environment (Mason et al. 2002; Bubner et al. 2004). However, this would not be the case for transgenic plants that are derived from single cells, where every cell in the plant would have the stably integrated transgene. Similar findings have also been observed in maize transformed with $B t$ gene, where the expression of reporter genes at the protein level is indirectly implied. This led to the development of a direct detection method for protein expression of the gene of interest (Sardana et al. 1996). However, our approach gives a more accurate picture on the of transcription level of the gene of interest in oil palm. For example, it was found that, the $\operatorname{CryIA(b)}$ 
transcripts were relatively little compared to the GUS protein expression observed in the transformed IEs. This approach could also serve as an important tool in promoter study, as it would be more precise to evaluate promoter efficiency at the transcription level as compared to the protein level, since it will not be influence by translational factors.

In conclusion, this paper provides the first evidence on the functionality of a transgene in oil palm following transformation. In addition, this detection technique that combines RT-PCR and Southern blotting is highly sensitive in detecting minute traces of transgenes expression in putative transformed plants. It is a useful a tool that enable closer expression studies of individual genes at the cellular level where transcripts analyses could be carried out immediately following transformation. This is especially important for crops with slow growth rate such as oil palm. In addition, the system also allows for the detection of mRNA expression reflecting biological phenomena in minute amount of cells and also for accurate evaluation of essential but lowly expressed mRNA in transgenic plants.

\section{ACKNOWLEDGEMENTS}

The authors would like to thank Prof. Illimaar Altoosaar, Ottawa University, Canada, for the crylA(b) gene; Dr. Richard A. Jefferson, CAMBIA, Australia, for the pCAMBIA1301 cloning vector; Dr. J. K. Kim, Myongji University, Korea, for the rubisco promoter and Universiti Kebangsaan Malaysia (UKM) for research facilities.

\section{REFERENCES}

ABDULLAH, R.; CHARI, C.; YAP, W.S.P. and YEUN, L.H. Transgenic oil palm with stably integrated CpTI gene confers resistance to bagworm larvae. In: VASIL, I.K. ed. Plant Biotechnology 2002 and Beyond: A celebration and a showcase. Kluwer Academic Publishers, 2003, p.163-165.

ABDULLAH, R.; ALIZAH, Z.; WEE, Y.H.; LEAW, C.L.; YEAP, C.B.; YAP, W.S.P.; YEUN, L.H.; RASHDAN, M.M.; JOSEPH, J.L.; SITI AZMA, J.; LEE, M.P. and SALWA, A.S. Immature Embryo: A useful tool for oil palm genetic transformation studies. Electronic Journal of Biotechnology [online]. 15 April 2005, vol. 8, no. 1. Available from Internet: http://www.ejbiotechnology.info/content/vol8/issue1/full/1. ISSN 07173458.

ABEDINIA, M.; HENRY, R.J.; BLAKENEY, A.B. and LEWIN, L. An efficient transformation system for the Australian rice cultivar, Jarrah. Australian Journal of Plant Physiology, 1997, vol. 24, no. 2, p. 133-141.

BHATTACHARYA, R.C.; VISWAKARMA, N.; BHAT, S.R.; KIRTI, P.B. and CHOPTA, V.L. Development of insect-resistant transgenic cabbage plants expressing a synthetic cryIA(b) gene from Bacillus thuringiensis. Current Science, July 2002, vol. 83, no. 2, p. 146-150.
BUBNER, Ben; GASE, Klaus and BALDWIN, Ian T. Two-fold differences are the detection limit for determining transgene copy numbers in plants by real-time PCR. $B M C$ Biotechnology, July 2004, vol. 4, p. 14.

CHENG, Xiongying; SARDANA, Ravinder; KAPLAN, Harvey and ALTOSAAR, Illimar. Agrobacteriumtransformed rice plants expressing synthetic $\operatorname{cry} I A(b)$ and $\operatorname{cryIA(c)}$ genes are highly toxic to striped stem borer and yellow stem borer. Proceedings of the National Academy of Sciences of the United States of America, March 1998, vol. 95 , no. 6, p. 2767-2772.

CHOWDHURY, M.K.U. Evaluation of five promoters for use in transformation of oil palm (Elaeis guineensis Jacq.). Plant Cell Reports, February 1997, vol. 16, no. 5, p. 277 281.

DOYLE, J.J. and DOYLE, J.L. Isolation of plant DNA from fresh tissue. FOCUS, 1990, vol. 12, p. 13-15.

DEHESH, Katayoon; TAI, Heeyoung Y.; EDWARDS, Patricia; BYRNE, James and JAWORSKI, Jan G. Overexpression of 3-ketoacyl-acyl-carrier protein synthase IIIs in plants reduces the rate of lipid synthesis. Plant Physiology, February 2001, vol. 125, no. 2, p. 1103-1114.

EBINUMA, H.; SUGITA, K.; MATSUNAGA, E.; ENDO, S.; YAMADA, K. and KOMAMINE, A. Systems for the removal of selection marker and their combination with a positive marker. Plant Cell Reports, July 2001, vol. 20, no. 5, p. 383-392.

FRANCIS, Kirk E. and SPIKER, Steven. Identification of Arabidopsis thaliana transformants without selection reveals a high occurrence of silenced T-DNA integrations. The Plant Journal, February 2005, vol. 41, no. 3, p. 464477.

GERALD, K. Cell and Molecular Biology: Concepts and Experiments, $3^{\text {rd }}$ Ed. 2002. John Wiley and Sons. New York. USA. 785 p. ISBN 0471389137.

HIGUCHI, R.; DOLLINGER, G.; WALSH, P.S. and GRIFFITH, R. Simultaneous amplification and detection of specific DNA sequences. Bio/Technology, April 1992, vol. 10, no. 4, p. 413-417.

HOHE, A. and RESKI, R. A tool for understanding homologous recombination in plants. Plant Cell Reports, August 2003, vol. 21, no. 12, p. 1135-1142.

JAIN, S.M. and MINOCHA, S.C. Molecular Biology of Woody Plants. Volume 2, 2000. Agritech Publications/Agri Cell Reports, New York, USA. 511 p. ISBN 0792362411.

JIANG, Junda; LINSCOMBE, Steve D.; WANG, Jianlin and OARD, James H. High efficiency transformation of U.S. rice lines from mature seed-derived calli and segregation of glufosinate resistance under field conditions. 
Crop Science, November-December 2000, vol. 40, no. 6, p. 1729-1741.

JIN, Wei-Wei; LI, Zong-Yun; FANG, Qing; ALTOSAAR, Illimar; LIU, Li-Hua and SONG, Yun-Chun. Fluorescence in situ hybridization analysis of alien genes in Agrobacterium-mediated CrylA(b)-transformed rice. Annals of Botany, July 2002, vol. 90, no. 1, p. 31-36.

JOUANIN, Lise; BONADE-BOTTINO, Michel; GIRARD, Cécile; MORROT, Gil and GIBAND, Marc. Transgenic plants for insect resistance. Plant Science, January 1998, vol. 131, no. 1, p. 1-11.

KINNEY, Anthony J.; JUNG, Rudolf and HERMAN, Eliot M. Cosuppression of the $\alpha$ subunits of $\beta$-conglycinin in transgenic soybean seeds induces the formation of endoplasmic reticulum-derived protein bodies. The Plant Cell, May 2001, vol. 13, no. 5, p. 1165-1178.

KLEIN, T.M.; GRADZIEL, T.; FROMM, M.E. and SANFORD, J.C. Factors influencing gene delivery into Zea mays cells by high-velocity microprojectiles. Bio/Technology, 1988, vol. 6, no. 5, p. 559-563.

KOTA, R.; HOLTON, T.A. and HENRY, R.J. Detection of transgenes in crop plants using molecular beacon assays. Plant Molecular Biology Reporter, 1999, vol. 17, no. 4, p. 363-370.

MASSON, Luke; TABASHNIK, Bruce E.; LIU, YongBiao; BROUSSEAU, Roland and SCHWATRZ, JeanLouis. Helix 4 of the Bacillus thuringiensis CrylAa toxin lines the lumen of the ion channel. Journal of Biological Chemistry, November 1999, vol. 274, no. 45, p. 3199632000 .

MASON, Giovanna; PROVERO, Paolo; VAIRA, Anna Maria and ACCOTTO, Gian Paolo. Estimating the number of integrations in transformed plants by quantitative realtime PCR. BMC Biotechnology, October 2002, vol. 2, p. 20-30.

MAYES, S.; JACK, P.L. and CORLEY, R.H.V. The use of molecular markers to investigate the genetic structure of an oil palm breeding programme. Heredity, September 2000, vol. 85 , no. 3, p. 288-293.

MITSUHARA, Ichiro; SHIRASAWA-SEO, Naomi; IWAI, Takayoshi; NAKAMURA, Shigeo; HONKURA, Ryoso and OHASHI, Yuko. Release from post-transcriptional gene silencing by cell proliferation in transgenic tobacco plants: possible mechanism for non-inheritance of the silencing. Genetics, January 2002, vol. 160, no. 1, p. 343352.

OSORIO, J.; FERNANDEZ-MARTINEZ, J.M.; MANCHA, M. and GARCES, R. Mutant sunflowers with high concentration of saturated fatty acids in the oil. Crop Science, 1995, vol. 35, no. 3, p. 739-742.
PASTERNAK, Taras P.; PRINSEN, Els; AYAYDIN, Ferhan; MISKOLCZI, Pál; POTTERS, Geert; ASARD, Han; VANONCKELEN, Harry A.; DUDITS, Dénes and FEHER, Attila. The role of auxin, $\mathrm{pH}$, and stress in the activation of embryogenic cell division in leaf protoplastderived cells of alfalfa. Plant Physiology, August 2002, vol. 129, no. 4, p. 1807-1819.

PFAFFL, Michael W. and HAGELEIT, M. Validities of mRNA quantification using recombinant RNA and recombinant DNA external calibration curves in real-time PCR. Biotechnology Letters, February 2001, vol. 23, no. 4, p. 275-282.

RAMACHANDRAN, Suresh; BUNTIN, G. David; ALL, John N.; RAYMER, Paul L. and STEWART, C. Neal Jr. Intraspecific competition of an insect-resistant transgenic canola in seed mixtures. Agronomy Journal, March-April 2000, vol. 92, no. 2, p. 368-374.

REARDON, B.J.; HELLMICH, R.L.; SUMERFORD, D.V. and LEWIS L.C. Growth, development, and survival of Nosema pyrausta-infected European Corn Borers (Lepidoptera: Crambidae) reared on meridic diet and CrylAb. Journal of Economic Entomology, August 2004, vol. 97 , no. 4, p. 1198-1201.

ROBINSON, J. Ethics and transgenic crops: A review. Electronic Journal of Biotechnology [online]. 15 August 1999, vol. 2, no. 2 [cited date]. Available from Internet: http://www.ejbiotechnology.info/content/vol2/issue2/full/3. ISSN 07173458.

SAMBROOK, J.; FRITSCH, E.F. and MANIATIS, T. Molecular cloning: a laboratory manual. $3^{\text {rd }}$ Edition, 2001. Cold Spring Harbor Laboratory Press. New York, USA. 1.1-7. 94 p. ISBN 087969-576-5.

SARDANA, Ravinder; DUKIANDJIEV, Stefan; GIBAND, Marc; CHENG, Xiongying; COWAN, Kyra; SAUDER, Connie and ALTOSAAR, Illimar. Construction and rapid testing of synthetic and modified toxin gene sequences $C r y 1 \mathrm{~A}(b \& c)$ by expression in maize endosperm culture. Plant Cell Reports, May 1996, vol. 15, no. 9, p. 677-681.

SHARMA, H.C.; SHARMA, K.K.; SEETHARAMA, N. and ORTIZ, R. Prospects for using transgenic resistance to insects in crop improvement. Electronic Journal of Biotechnology [online]. 15 August, vol. 3, no. 2 [cited date]. Available from Internet: http://www.ejbiotechnology.info/content/vol3/issue2/full/3. ISSN 07173458.

SHARMA, H.C.; CROUCH, J.H.; SHARMA, K.K.; SEETHARAMA, N. and HASH, C.T. Applications of biotechnology for crop improvement: prospects and constraints. Plant Science, September 2002, vol. 163, no. 3, p. 381-395. 
SZITTYA, György; SILHAVY, Dániel; MOLNAR, Attila; HAVELDA, Zoltán; LOVAS, Agnes; LAKATOS, Lóránt; BANFALVI, Zsófia and BURGYAN, József. Low temperature inhibits RNA silencing-mediated defence by the control of siRNA generation. The EMBO Journal, February 2003, vol. 22, no. 3, p. 633-640.

STAM, Maike; VITERBO, Ada; MOL, Joseph N.M. and KOOTER, Jan M. Position-dependent methylation and transcriptional silencing of transgenes in inverted T-DNA repeats: Implications for post-transcriptional silencing of homologous host genes in plants. Molecular and Cellular Biology, November 1998, vol. 18, no. 11, p. 6165-6177.

STANGELAND, Biljana and SALEHIAN, Zhian. An improved clearing method for GUS assay in Arabidopsis endosperm and seeds. Plant Molecular Biology Reporter, June 2002, vol. 20, no. 2, p. 107-114.

SU, Jin; SHEN, Qingxi; HO, Tuan-Hua David and WU, Ray. Dehydration-stress-regulated transgene expression in stably transformed rice plants. Plant Physiology, July 1998, vol. 117, no. 3, p. 913-922.

TANG, Wei and TIAN, Yingchuan. Transgenic loblolly pine (Pinus taeda L.) plants expressing a modified $\delta$ endotoxin gene of Bacillus thuringiensis with enhanced resistance to Dendrolimus punctatus Walker and Crypyothelea formosicola Staud. Journal of Experimental Botany, February 2003, vol. 54, no. 383, p. 835-844.

TINLAND, Bruno. The integration of T-DNA into plant genomes. Trends in Plant Science, June 1996, vol. 1, no. 6, p. $178-184$.

TZFIRA, Tzvi and CITOVSKY, Vitaly. Partners-ininfection: host proteins involved in the transformation of plant cells by Agrobacterium. Trends in Cell Biology, March 2002, vol. 12, no. 3, p. 121-129.

VERWOERD, T.C.; DEKKER, B.M.M. and HOEKEMA, A. A small-scale procedure for the rapid isolation of plant RNAs. Nucleic Acid Research, March 1989, vol. 17, no. 6, p. 2362.

WOOD, B.J. Pests of oil palms in Malaysia and their control. The Incorporated Society of Planters, 1968. Kuala Lumpur, Malaysia. 204 p. ASIN 0B0007JC5AC.

WRIGHT, M.; DWASON, J.; DUNDER, E.; SUTTE, J.; REED, J.; KRAMER, C.; CHANG, Y.; NOVITSKY, R.; WANG, H. and ARTIM-MOORE, L. Efficient biolistic transformation of maize (Zea mays L.) and wheat (Triticum aestivum L.) using the phosphomannose isomerase gene, pmi, as the selectable marker. Plant Cell Reports, July 2001, vol. 20, no. 5, p. 429-436.

YANG, J.; LEE, H-J.; SHIN, D.H.; OH, S.K.; SEON, J.H.; PAEK, K.Y. and HAN, K.H. Genetic transformation of
Cymbidium orchid by particle bombardment. Plant Cell Reports, September 1999, vol. 18, no. 12, p. 978-984. 